\title{
HUBUNGAN UMUR DAN KONSUMSI MAKANAN MENGANDUNG ZAT BESI DENGAN ANEMIA PADA IBU HAMIL DI PUSKESMAS TALISE PALU
}

\author{
Susan Elviyaningsih ${ }^{1 \mathrm{~K}}$, Rafika ${ }^{2}$, Putu Candriasih ${ }^{3}$ \\ ${ }^{1}$ Prodi DIV Kebidanan, Jurusan Kebidanan Poltekkes Kemenkes Palu \\ ${ }^{2}$ Prodi DIII Kebidanan, Jurusan Kebidanan Poltekkes Kemenkes Palu \\ ${ }^{3}$ Jurusan Gizi Poltekkes Kemenkes Palu \\ email Penulis Korespondensi $\left({ }^{\mathrm{K}}\right)$ : susanelnianingsih@gmail.com
}

\begin{abstract}
Anemia in pregnant women is called a potential that endangers the mother and child, therefore anemia requires serious attention from parties involved in health services. The purpose of this study is to know the relationship of age and consumption of iron-containing foods with the incidence of anemia in pregnant women in Talise Palu Health Center in 2017. The type of research is descriptive comparative using a cross sectional approach. The population of all pregnant women in the Talise Health Center area. The sample in this study amounted to 55 respondents with the sampling technique using consecutive sampling technique. The data collection is done through direct interviews and direct $\mathrm{Hb}$ measurements. Data analysis using univariate frequency distribution and bivariate analysis with Fisher's Exact Test. The results of the study of 55 respondents there were $96.4 \%$ of pregnant women who had anemia, with the age of pregnant women not at risk of $85.5 \%$ and pregnant women who rarely consumed foods containing iron there were $78.2 \%$. The results of statistical tests using Fisher's Exact Test showed that there was a relationship between consumption of iron-containing foods $(p=0.04)$ with the incidence of anemia in pregnant women at Talise Palu Health Center in 2017 and no age relationship $(p=0.728)$ with anemia in pregnant women. Conclusion that age has no relationship with the incidence of anemia in pregnant women. Consumption of iron-containing foods is associated with the incidence of anemia in pregnant women. Suggestions for midwives who work at the KIA-KB Poli to continue to provide services according to operational standards during pregnancy examinations so that anemia in pregnant women can be treated and even prevented during pregnancy.
\end{abstract}

Keywords: Pregnant, Anemia, consumption of foods containing iron

\section{PENDAHULUAN}

\section{Latar Belakang}

Anemia selama kehamilan akan memberikan pengaruh kepada ibu pada kehamilan dan persalinan berupa lemah, anoreksia, perdarahan, preeklampsia, infeksi, sepsis puerperalis, persalinan lama, persalinan prematur, dan perdarahan pasca persalinan sedangkan pengaruh pada janin berupa abortus, lahir mati, cacat bawaan, anemia pada bayi ${ }^{(1)}$. Status kehamilan juga dapat memengaruhi derajat anemia, semakin sering seorang ibu melahirkan maka semakin besar resiko kehilangan darah dan berdampak pada penurunan $\mathrm{Hb}{ }^{(2)}$.

Hasil penelitian Abrihe tahun $2014^{(3)}$ menjelaskan bahwa ibu hamil yang memiliki frekuensi makan kurang dari duakali perhari adalah 3,9 kali berisiko tinggi terkena anemia dibandingkan mereka yang frekuensi makan lebih dari tigakali perhari. Hal ini disebabkan bahwa kehamilan adalah periode khusus dengan peningkatan energi dan kebutuhan nutrisi 
yang dapat dipenuhi dengan peningkatan frekuensi makan serta konsumsi daging merupakan faktor lain yang menunjukan hubungan yang signifikan dengan anemia pada wanita hamil. Wanita hamil dengan kebiasaan makan daging seminggu sekali berisiko 2,2 kali lebih tinggi terkena anemia dibandingkan ibu hamil yang makan daging lebih dari duakali per minggu. Peningkatan konsentrasi hemoglobin dengan fakta bahwa daging merah merupakan sumber penting dari besi heme.

Anemia dipengaruhi secara langsung oleh konsumsi makanan sehari-hari yang kurang mengandung zat besi, secara umum konsumsi makanan berpengaruh terhadap status gizi seseorang dan juga dipengaruhi oleh faktor-faktor antara lain seperti umur, jenis kelamin, tingkat pendidikan, tingkat ekonomi dan lingkungan sosial budaya ${ }^{(4)}$.

Umur seorang wanita yang sedang hamil sebaiknya tidak terlalu muda dan tidak terlalu tua. Umur yang kurang dari 20 tahun atau yang lebih dari 35 tahun beresiko tinggi untuk hamil. Kesiapan seorang wanita untuk hamil atau mempunyai anak ditentukan oleh kesiapan dalam tiga hal, yaitu kesiapan fisik, kesiapan mental, emosi psikologi dan kesiapan sosial ekonomi. Secara umum seorang wanita disebut siap secara fisik jika ia telah menyelesaikan pertumbuhan tubuhnya, yaitu sekitar umur 20 tahun sedangkan wanita yang belum mencapai umur 20 tahun, sedang dalam proses pertumbuhan dan perkembangan fisik karena tubuhnya belum berkembang secara maksimal, ini berdampak pada meningkatnya risiko kehamilan. Bahaya yang ditimbulkan diantaranya anemia ${ }^{(5)}$.

Penelitian yang dilakukan Astuti tahun $2014^{(6)}$ dari jumlah ibu hamil 36 orang diperoleh 21 orang tergolong anemia dengan umur $<20$ tahun dan 15 orang tergolong anemia dengan umur $\geq 20$ tahun. Hal ini menunjukan bahwa pada dasarnya usia ibu hamil dapat mempengaruhi anemia jika usia ibu hamil muda $<20$ tahun, karena pada umur tersebut masih terjadi pertumbuhan yang membutuhkan zat gizi lebih banyak.

Hasil survey pendahuluan diperoleh dari Puskesmas Talise pada tahun 2015 jumlah sasaran ibu hamil sebanyak 739 orang yang diperiksa Hb yaitu 176 orang dan tergolong anemia sebesar 153 orang dengan presentase (86,9\%). Pada tahun 2016 bulan Januari sampai dengan Nopember 2016 sasaran ibu hamil 743 orang, yang diperiksa Hb 666 orang dan tergolong anemia ringan berjumlah 155 orang dan anemia sedang berjumlah 274 orang.

\section{Tujuan}

Tujuan penelitian untuk mengetahui hubungan umur dan konsumsi makanan mengandung zat besi dengan anemia pada ibu hamil di puskesmas Talise Palu.

\section{METODE PENELITIAN}

Jenis penelitian adalah deskriptif komparatif dengan desain cross sectional. Untuk melihat hubungan umur dan konsumsi makanan mengandung zat besi dengan anemia pada ibu hamil. Penelitian ini dilaksankan di wilayah Puskesmas Talise kota Palu pada bulan Maret 2017. Populasi dalam penelitian ini adalah semua ibu hamil yang ada di wilayah kerja Puskesmas Talise pada bulan Maret 2017 berjumlah 122 orang. Sampel dalam penelitian ini berjumlah 55 orang. Teknik pengambilan sampel menggunakan teknik Conseccutive Sampling dengan kriteria inklusi dalam penelitian ini adalah:

a. Ibu hamil trimester I, II dan III

b. Bersedia dilakukan pengambilan darah untuk pemeriksaan $\mathrm{Hb}$

c. Ibu mempunyai status lengkap (data ibu hamil tentang penyakit kronik)

d. Ibu bersedia menjadi responden dengan menandatangani informed consen .

Pengumpulan sampel berupa umur responden yang diperoleh dengan wawancara menggunakan kuisioner dan data pola konsumsi makanan mengandung zat besi

2 | Penerbit: Jurusan Kebidanan, Poltekkes Kemenkes Palu 
menggunakan formulir FFQ yang akan diberi skor sesuai pilihan responden, 50 jika memilih $>1 \mathrm{x}$ sehari, 25 jika memilih 1x sehari, 15 jika memilih 3-6x seminggu, 10 jika memilih 1-2x seminggu, 1 jika memilih 1-2x/bulan dan 0 jika tidak pernah sama sekali, setelah itu jawaban responden dikategorikan menjadi 2 yaitu "sering " jika rata rata responden mengkonsumsi makanan sumber zat besi $\geq 3 \mathrm{x} /$ seminggu dan "jarang" jika mengkonsumsi $<3 /$ kali seminggu. Pengukuran $\mathrm{Hb}$ dilakukan dengan pengambilan darah pada lengan ibu hamil, selanjutnya di periksa di laboratorium dengan menggunakan alat hematologis analizer. Pengolahan data mulai editing, coding, prosessing, cleaning. Analisis univariat dengan distribusi frekuensi dan analisis bivariat Fisher's Exact Test.

\section{HASIL PENELITIAN}

Data sampel karakteristik ibu hamil terdiri dari pendidikan, pekerjaan dan pendapatan keluarga Tabel berikut ini.

Tabel 1

Distribusi frekuensi Responden berdasarkan karakterisik ibu hamil di Puskesmas Talise

\begin{tabular}{lcc}
\hline \multicolumn{1}{c}{ Karakteristik } & f & \% \\
\hline Pendidikan & 5 & \\
$\quad$ SD & 7 & 9,1 \\
SMP & 26 & 12,7 \\
SMU & 17 & 47,3 \\
Perguruan tinggi & & 30,9 \\
Pekerjaan & 24 & 43,6 \\
$\quad$ Bekerja & 31 & 56,4 \\
$\quad$ Tidak bekerja & 3 & 5,5 \\
Pendapatan keluarga & 30 & 54,5 \\
$\quad<1.000 .000$ & 22 & 40,0 \\
1.000.000-3.000.000 & & \\
$>3.000 .000$ & &
\end{tabular}

Pada Tabel 1. Diantaranya terdapat responden paling banyak adalah berpendidikan SMU sebesar 47,3\% dan paling sedikit berpendidikan SD sebesar 9,1\%. Responden yang tidak bekerja sebesar 56,4\% lebih banyak dari responden yang bekerja sebesar $43,6 \%$. Pendapatan keluarga, responden yang paling banyak berpenghasilan 1.000.000-3.000.000 sebesar 54,5\%, sedangkan yang paling sedikit responden berpenghasilan 1.000 .000 adalah $5,4 \%$.

Tabel 2

Distribusi frekuensi umur ibu hamil di Puskesmas Talise

\begin{tabular}{lcc}
\hline Kelompok umur (Tahun) & $\mathrm{f}$ & $\%$ \\
\hline $20-35$ & 47 & 85,5 \\
$<20->35$ & 8 & 14,5 \\
\hline Total & 55 & 100 \\
\hline
\end{tabular}

Tabel 2 menunjukkan data distribusi umur ibu hamil diperoleh hampir seluruh $(85,5 \%)$ responden memiliki umur 20-35 tahun. 
Tabel 3

Distribusi frekuensi konsumsi makanan mengandung zat besi ibu hamil di Puskesmas Talise

\begin{tabular}{lcc}
\hline Konsumsi makanan zat besi & $\mathrm{f}$ & $\%$ \\
\hline Sering & 12 & 21,8 \\
Jarang & 43 & 78,2 \\
\hline Total & $\mathbf{5 5}$ & $\mathbf{1 0 0}$ \\
\hline
\end{tabular}

Tabel 3 menunjukkan data distribusi konsumsi makanan mengandung zat besi ibu hamil di Puskesmas Talise diperoleh sebagian besar (78,2\%) responden dengan jarang konsumsi makanan mengandung zat besi.

Tabel 4

Distribusi frekuensi anemia pada ibu hamil di Puskesmas Talise

\begin{tabular}{lcc}
\hline Kejadian Anemia & $\mathrm{f}$ & $\%$ \\
\hline Tidak Anemia & 2 & 3,6 \\
Anemia & 53 & 96,4 \\
\hline Total & 55 & 100 \\
\hline
\end{tabular}

Berdasarkan hasil tabel 4 diperoleh hampir seluruh (96,4\%) responden mengalami anemia dalam kehamilan.

Tabel 5

Distribusi hubungan Umur dengan kejadian Anemia pada ibu hamil di Puskesmas Talise Tahun 2017

\begin{tabular}{|c|c|c|c|c|c|}
\hline \multirow{2}{*}{ Umur } & \multicolumn{2}{|c|}{ Anemia } & \multicolumn{2}{|c|}{ Tidak Anemia } & \multirow[t]{2}{*}{$p$} \\
\hline & $\mathrm{f}$ & $\%$ & $f$ & $\%$ & \\
\hline $20-30$ & 2 & 4 & 45 & 96 & \\
\hline$<20 \&>30$ & 0 & 0 & 8 & 100 & 0,72 \\
\hline Total & 2 & 4 & 53 & 96 & \\
\hline
\end{tabular}

Tabel 6 menunjukkan bahwa 45 (96\%) responden dengan umur 20-30 tahun yang mengalami anemia. Hasil statistic uji Fisher's Exact Test diperoleh nilai p-value 0,72. Oleh karena nilai $p$-value $=0,72>\alpha(0,05)$, maka dapat disimpulkan tidak ada hubungan yang signifikan antara umur dengan anemia pada ibu hamil.

Tabel 6

Hubungan konsumsi makanan mengandung zat besi dengan kejadian anemia pada ibu hamil di Puskesmas Talise

\begin{tabular}{ccccccc}
\hline \multirow{2}{*}{$\begin{array}{c}\text { Konsumsi makanan } \\
\text { mengandung zat besi }\end{array}$} & \multicolumn{4}{c}{ Anemia } & Total & P Value \\
\cline { 2 - 5 } & $\begin{array}{c}\text { Tidak } \\
\text { anemia }\end{array}$ & anemia & & & \\
\cline { 2 - 5 } & $\mathrm{f}$ & $\%$ & $\mathrm{f}$ & $\%$ & & \\
\hline Sering & 2 & 17 & 10 & 83 & & 12 \\
Jarang & 0 & 0 & 43 & 100 & 43 & 0,04 \\
\hline Total & 2 & 4 & 53 & 96 & 55 & \\
\hline
\end{tabular}

4 | Penerbit: Jurusan Kebidanan, Poltekkes Kemenkes Palu 
Dalam tabel 5 terdapat 43 responden yang jarang mengonsumsi makanan mengandung zat besi dengan tidak anemia. Hasil statistik uji Fisher's Exact Test diperoleh nilai $p$-value $=0,04$. Oleh karena nilai $p=0,04<\alpha=0,05$ berarti ada hubungan antara konsumsi makanan mengandung zat besi dengan kejadian anemia.

\section{PEMBAHASAN}

Hasil penelitian berdasarkan umur tersebut bahwa umur bukanlah salah satu faktor penyebab terjadinya anemia melainkan ada faktor lain yang mempengaruhi anemia pada ibu hamil. Anemia pada ibu hamil terjadi karena adanya kecenderungan rendahnya cadangan zat besi dalam tubuh yang disebabkan oleh berbagai macam faktor seperti pola konsumsi zat besi, peningkatan kebutuhan zat besi, penyakit infeksi, dan perdarahan yang banyak pada saat menstruasi dan persalinan.

Hasil penelitian ini didukung oleh penelitian Qudsiah tahun $2013^{(7)}$ bahwa tidak ada hubungan yang signifikan antara umur dengan kejadian anemia, hal ini disebabkan bahwa umur bukan satu satunya faktor penyebab anemia melainkan ada faktor lain yaitu faktor dasar (sosial ekonomi, pengetahuan, pendidikan dan budaya) dan faktor langsung (pola konsumsi $\mathrm{Fe}$, penyakit infeki dan perdarahan).

Hasil penelitian Besuni tahun $2013^{(8)}$ bahwa keseimbangan zat besi dalam tubuh dapat dipertahankan selama kehamilan jika tersedia cadangan besi yang mencukupi saat mulai hamil. Seorang wanita yang rutin mengkonsumsi makanan yang mengandung zat besi dalam jumlah besar diharapkan mempunyai cadangan zat besi sebelum kehamilannya yang besarnya $300 \mathrm{mg}$ mencukupi, untuk diet yang kurang optimal akan dibutuhkan cadangan zat besi dalam jumlah yang lebih tinggi. Hal ini sejalan dengan teori Sukarni dan Margareth (9) menjelaskan kekurangan zat besi sejak sebelum hamil tidak diatasi dapat mengakibatkan ibu hamil dapat menderita anemia.

Faktor risiko terjadinya anemia pada kehamilan jika mengalami menstruasi berat sebelum kehamilan dan juga kehilangan banyak darah pada saat cidera atau operasi (10). Faktor resiko terjadinya anemia pada wanita, pendarahan pasca partum akibat perawatan obstetric yang buruk, kehamilan yang berkali-kali dengan jarak antar kehamilan yang pendek, periode laktasi yang panjang, dan penggunaan IUD (11). Teori tersebut sesuai dengan pendapat Irianto tahun $2014^{(5)}$, anemia pada kehamilan disebabkan adanya kecenderungan rendahnya cadangan zat besi $(\mathrm{Fe})$ pada wanita akibat persalinan sebelumnya dan menstruasi. Anemia juga bisa dicegah dengan mengatur jarak kehamilan atau kelahiran bayi. Makin sering seorang wanita mengalami kehamilan dan melahirkan, akan makin banyak kehilangan zat besi dan menjadi semakin anemia. Hal ini didukung hasil penelitian Sumiaty tahun 2017 (2) bahwa ibu yang mengalami perdarahan postpartum lebih berisiko terjadi pada ibu yang mengalami anemia dalam kehamilan dan jarak persalinan $<2$ tahun. Hal ini didasarkan hasil analisis bivariat diperoleh ada hubungan antara anemia dalam kehamilan (nilai p:0,000) dan jarak persalinan (nilai p:0,000) dengan kejadian perdarahan postpartum. Ibu yang anemia memiliki risiko 28 kali untuk mengalami perdarahan postpartum $(\mathrm{OR}=28,571)$, sedangkan ibu yang jarak persalinan $<2$ tahun memiliki risiko 19 kali untuk mengalami perdarahan postpartum $(\mathrm{OR}=19,3)$.

Hasil analisis bivariat diperoleh ada hubungan antara konsumsi makanan mengandung zat besi dengan anemia pada ibu hamil, hal ini didukung hasil uji statistik dengan Fisher's Exact Test $\mathrm{p}=0,044$, bahwa ibu hamil yang jarang mengkonsumsi makanan mengandung zat besi lebih banyak mengalami anemia dibandingkan ibu hamil yang sering mengkonsumsi makanan mengandung zat besi. Hal ini dikarenakan ibu hamil membutuhkan asupan makanan

5 | Penerbit: Jurusan Kebidanan, Poltekkes Kemenkes Palu 
dengan kandungan zat besi yang lebih tinggi. Semakin tinggi asupan makanan mengandung zat besi, maka kadar hemoglobin semakin baik.

Dalam mengkonsumsi makanan zat besi perlu mempertimbangkan jenis makanan tingkat absorpsinya tinggi yang terdapat dalam bahan makanan hewani seperti daging, unggas, dan ikan sedangkan zat besi dengan absorpsinya rendah umumnya terdapat dalam tumbuhtumbuhan, seperti serelia, kacang-kacangan dan sayur-sayuran. Keterbatasan dalam pemilihan jenis makanan yang mengandung zat besi, erat kaitannya dengan pengatahuan yang dimiliki ibu hamil, yang di peroleh dari pendidikan. Begitu pulu pekerjaan dan pendapatan keluarga merupakan faktor pendukung dalam pemilihan makanan yang akan dikonsumsi sehari-harinya.

Hal ini sejalan dengan penelitian Hidayat tahun $2013^{(4)}$ menyatakan anemia dipengaruhi secara langsung oleh konsumsi makanan sehari-hari yang kurang mengandung zat besi, secara umum konsumsi makanan berpengaruh terhadap status gizi seseorang dan juga dipengaruhi oleh faktor-faktor antara lain seperti umur, jenis kelamin, tingkat pendidikan, tingkat ekonomi dan lingkungan sosial budaya. Menurut pendapat Astuti tahun 2014 (6) mengatakan tingkat pendidikan ibu hamil dapat menyebabkan keterbatasan dalam upaya penanganan masalah gizi dan kesehatannya. Pengetahuan gizi dalam kesehatan akan berpengaruh terhadap pola konsumsi makanan mengandung zat besi. Semakin tinggi pendidikan tentang gizi dengan kesehatan, semakin beragam pula jenis makanan yang dikonsumsi sehingga dapat memenuhi kecukupan gizi dan mempertahankan kesehatan individu.

Makan makanan yang tidak mengandung zat besi akan mengakibatkan pasokan darah ke janin dan pasokan darah ke ibu berkurang dan menyebabkan terjadinya anemia. Ibu hamil membutuhkn lebih banyak zat besi selama kehamilan. Mengkonsumsi makanan yang kaya akan zat besi bersamaan dengan makanan yang kaya vitamin $\mathrm{C}$ akan meningkatkan penyerapan mineral dalam tubuh. Cara paling mudah untuk mendapatkan zat besi adalah dengan memakan makan berbagai jenis makanan yang kaya akan zat besi ${ }^{(12)}$.

Hal ini sejalan dengan penelitian Besuni tahun $2013^{\left({ }^{(8)}\right.}$ bahwa ada pengaruh antara konsumsi makanan yang mengandung zat besi dengan kejadian anemia pada ibu hamil. Semakin tinggi asupan zat besi, maka kadar hemoglobin semakin baik. Besi merupakan komponen utama dalam pembentukan darah (hemopoiesis). Apabila simpanan besi cukup, maka kebutuhan untuk pembentukan sel darah merah terpenuhi. Namun apabila jumlah simpanan zat besi berkurang dan jumlah zat besi yang diperoleh dari makanan berkurang, maka akan terjadi ketidakseimbangan zat besi di dalam tubuh, yang berakibat kadar hemoglobin menurun dan menyebabkan anemia.

Hal ini juga didukung dengan hasil penelitian Abrihe tahun $2014^{(3)}$ bahwa ibu hamil yang memiliki frekuensi makan kurang dari dua kali per hari adalah 3,9 kali berisiko tinggi terkena anemia dibandingkan mereka yang frekuensi makan lebih dari tiga kali perhari. Hal ini disebabkan bahwa kehamilan adalah periode khusus dengan peningkatan energi dan kebutuhan nutrisi yang dapat dipenuhi dengan peningkatan frekuensi makan.dan juga wanita hamil dengan kebiasaan makan daging seminggu sekali berisiko 2,2 kali lebih tinggi terkena anemia dibandingkan ibu hamil yang makan daging lebih dari duakali per minggu. Peningkatan konsentrasi hemoglobin dengan fakta bahwa daging merah merupakan sumber penting dari besi heme.

Susilo tahun $2012^{(13)}$ bahwa asupan zat besi akan memberikan hubungan yang positif, yaitu setiap asupan $1 \mathrm{mg}$ zat besi akan memberikan sumbangan peningkatan kadar $\mathrm{Hb}$ sebesar 0,52g/dl. Menurut Irianto tahun $2014{ }^{(7)}$, anemia dapat dicegah dengan mengkonsumsi makanan bergizi seimbang dengan asupan zat besi yang cukup untuk memenuhi kebutuhan tubuh. Zat besi dapat diperoleh dengan mengkonsumsi daging

6 | Penerbit: Jurusan Kebidanan, Poltekkes Kemenkes Palu 
(terutama daging merah). Zat besi juga dapat ditemukan pada sayuran berwarna hijau gelap seperti bayam dan kangkung, buncis, kacang polong, serta kacang-kacangan.

Sesuai dengan pendapat Sukarni dan Margareth tahun 2013 (9) $^{(9)}$ bahwa kekurangan zat besi sejak sebelum hamil tidak diatasi dapat mengakibatkan ibu hamil dapat menderita anemia. Untuk memenuhi kekurangan tersebut ibu hamil harus memenuhi kebutuhan zat besinya yaitu sekitar 45-50 mg/hari. Kebutuhan itu dapat dipenuhi dari makanan yang kaya zat besi seperti daging berwarna, hati, ikan, kuning telur, sayuran berdaun hijau, kacangkacangan dan tempe.

\section{SIMPULAN DAN SARAN}

Berdasarkan hasil penelitian maka dapat disimpulkan bahwa tidak ada hubungan umur dengan kejadian anemia pada ibu hamil. Dan ada hubungan konsumsi makanan mengandung zat besi dengan anemia pada ibu hamil di puskesmas Talise. Saran penelitian adalah perlu dilakukan penelitian lanjutan agar dapat mengidentifikasi faktor lain seperti siklus menstruasi sebelum hamil, terjadinya pendarahan hebat sebelumnya, dan riwayat kehamilan terdahulu yang dapat menyebabkan anemia pada ibu hamil. Puskesmas Talise khususnya ruangan poli KIA-KB terus memberiakan pelayanan sesuai standar SOP sehingga beberapa faktor yang memungkinkan terjadinya anemia pada ibu hamil dapat diobati khususnya dapat di cegah agar prevelensi kejadian anemia dapat diturunkan.

\section{DAFTAR PUSTAKA}

1. Banudi, L. 2013. Gizi Kesehatan Reproduksi. Jakarta: EGC.

2. Sumiaty, Udin dan Aminuddin. 2017. Anemia Kehamilan dan Jarak Persalinan dengan kejadian Perdarahan Postpartum di RSUD Undata Palu Propinsi Sulawesi Tengah.. 4, Palu : Jurnal Husada Mahakam, , Vol. IV. 315-325.

3. Abrihe, A., Yusuf, ME., Wasesie, MM., 2014. Prevalence and associated factors of anemiaamong pregnant women of Mekelle town. (http://www.biomedcentral.com).

4. Hidayat, A., Citra, K., Fatimah. 2012. Hubungan Pola Makan dengan Kadar Hemoglobin Ibu Hamil Anemia Penerima Suplemen Zat Gizi Di Kabupaten Barru. (https://unhas.ac.id).

5. Irianto, K. 2014. Gizi Seimbang dalam Kesehatan Reproduksi. Bandung.Penerbit Alfabeta.

6. Astuti, D. 2014. Faktor Yang Berhubungan dengan Kejadian Anemia Pada Ibu Hamil Di Puskesmas Undaan Lor Kabupaten Kudus. .(https://.ums.ac.id).

7. Qudsiah, S., Herry, S., Siti, N. (2013). Hubungan antara Paritas dan Umur dengan Anemia pada Ibu Hamil Trimester III tahun 2012. Jurnal Kebidanan, Vol 2, No 1.

8. Besuni, A., Jafar, N., Indiasari, R., 2012. Hubungan Usupan Zat Gizi Pembentuk Sel Darah Merah dengan Kadar Hemoglobin Pada Ibu Hamil Di Kabupaten Gowa. (https://unhas.ac.id).

9. Sukarni dan Margareth. (2013). Kehamilan, Persalinan, dan Nifas. Yokyakarta: Nuha Medica.

10. Proverawati, A. (2011). Anemia dan Anemia Kehamilan. Yokyakarta: Nuha Medika.

11. Michael, G., Margaret, B., Karney, J., Arab, L., (2015). Gizi Kesehatan Masyarakat. Jakarta: EGC.

12. Daryono. 2013. Hubungan keteraturan mengkonsumsi tablet besi dan pola makan dengan anemia pada ibu hamil di Puskesmas Muara tembesi. Jurnal Kesehatan. Vol. 1V, No 1. (http://poltekkes-tjk.ac.id).

7 | Penerbit: Jurusan Kebidanan, Poltekkes Kemenkes Palu 
13. Susilo, J. Hadi, H. (2012). Hubungan Asupan Besi dan Inhibitornya, Sebagai Predictor Kadar Hemoglobin Ibu Hamil Di Kabupaten Bantul Propinsi DIY Jurnal berita kedokteran masyarakat. Vol 18, No. 1. 